\title{
Üniversite Kütüphanelerinin Mekânsal Tasarımının Kullanıcı Üzerindeki Etkisine İlişkin İstatistiki Bir Çalışma: Akdeniz Üniversitesi Merkez Kütüphanesi Örneği
}

\section{A Statistical Study on the Impact of Spatial Design on the User of University Libraries: The Case of Akdeniz University Central Library}

\author{
Hatice Hazal Emsen* ve Hilal Tuğba Örmecioğlu**
}

\section{$\ddot{\boldsymbol{O}} \boldsymbol{z}$}

Tarihte bilinen en eski kamusal yapı tiplerinden biri olarak asırlardır var olan kütüphane, bilgiye erişimi ve bilginin yaygınlaşmasını sağlayarak ülke gelişiminde önemli bir rol üstlenmektedir. Daha özel olarak üniversite kütüphaneleri ise, hitap ettiği kullanıcılardan ötürü, akademik gelişmelerin hızlanmasına yardımcı olmaktadır. Üniversite kütüphaneleri görevleri gereği, kullanıcıların her türlü bilimsel ihtiyaçlarını güvenilir ve hızlı bir şekilde karşılamak durumundadır. Ancak, teknolojinin ilerlemesiyle internetten kolaylıkla ulaşılabilen bilgi kaynaklarındaki artış, kullanıcıları kütüphaneden farklı mekânlarda da yapılabilecek bireysel araştırma imkânlarına yöneltmektedir. Bu koşullar altında varlığını korumaya çalışan kütüphanelerin ise mekânsal yapısı büyük önem kazanmıştır. Yapılan araştırmalar kullanıcıların kütüphane ziyaret süreleri ve sayılarının kütüphanelerin tasarımsal nitelikleri ve să̆ladıkları olanaklarla doğru orantılı olduğunu göstermektedir.

Bu çalışma, mimari tasarım ölçütleri ve kullanıcı görüşleri göz önünde bulundurularak elde edilen bazı faktörlerin kullanıcların kütüphane ziyaretine etkisini analiz etmeyi amaçlamaktadır. Bu kapsamda yapısal eşitlik modellemesi (YEM) bütün bu etkilerin tek bir model üzerinden yorumlanmasına olanak sağlayan bir yöntem olarak kullanılmıştır. Çalışma kapsamında daha önce doğrulanmış bir ölçek Akdeniz Üniversitesi Merkez Kütüphanesi için uyarlanmış ve 392 katılımcı ile uygulanan anketlerin verileri analiz edilerek sonuçları tartışılmıştır.

Anahtar Sözcükler: Faktör analizi; kütüphane tasarımı; üniversite kütüphanesi; yapısal eşitlik modellemesi.

\begin{abstract}
Library, as one of the oldest public building types known in history that have been existed for centuries, plays a substantial role in the development of countries by providing access to information and to spread it. More specifically, university libraries are helping to increase academic development because of their users. Due to their mission, university libraries have

\footnotetext{
* Yüksek Lisans Öğrencisi, Akdeniz Üniversitesi Mimarlık Bölümü. E-posta: hazalemsen@ gmail.com Graduate Student, Akdeniz University Department of Architecture, Turkey

** Doç. Dr., Akdeniz Üniversitesi Mimarlık Bölümü. E-posta: ormecioglu@akdeniz.edu.tr Associate Prof., Akdeniz University Department of Architecture, Turkey
} 
to provide all kinds of scientific needs of their users in a fast and reliable way. However, the increase in information sources that are easily accessible from the internet by the advancement of technology has allowed users to research in different places rather than library visits. Under these conditions, the spatial structure of a library that is trying to preserve its existence has gained significant importance. The researches have shown that the number and duration of library visits are directly proportional to the design qualities and the facilities provided by the library.

This study aims to analyze the effect of selected factors on the library visit of users by considering architectural design criteria and user opinion. In this context, structural equation modeling (SEM) has been utilized as a method that enables all these effects to be interpreted over a single model. Within the scope of the study, a previously validated scale was adapted for Akdeniz University Central Library; the data of 392 participants were analyzed, and the results were discussed.

Keywords: Factor analysis; library design; university library; structural equation modeling

\section{Giriş}

Bir ülkenin gelişmesindeki önemi yadsınamaz derecede büyük olan akademik eğitimin en önemli destekleyicileri üniversite kütüphaneleridir. Tüm kütüphane çeşitleri gibi üniversite kütüphaneleri de kullanıcılara kaynak ve çalışma ortamı sağlayarak işlevlerini sürdürmektedir. Ancak, çağın değişimiyle kütüphanelerin fonksiyonel özellikleri de kullanıcı gereksinimleri doğrultusunda farklılaşmaya başlamıştır. Üniversite kütüphanelerinin kullanıcıları sürekli ve geçici olarak ikiye ayrılmaktadır. Kütüphane görevlileri sürekli kullanıcı; öğrenci, öğretim üyesi, mezunlar, araştırmacılar, üniversitenin kütüphane harici birimlerinde çalışan personeli de geçici kullanıcılardır (Küçükcan, 2005, s. 128). Özellikle, genç nesli oluşturan öğrenciler üniversite kütüphanelerini bir çalışma alanı olarak görmekte ve çoğunlukla ders çalışma amaçlı kullanmaktadır. Araştırma amaçlı kullanımda ise kütüphane içerisindeki kitap nesnesini kaynak olarak kullanmak yerine, içinde bulunduğumuz dijital çağın getirisi olarak, çevrimiçi yollarla, bilgiye daha hızlı ve kolay ulaşım sağlamaktadır.

Dijital çağ ile birlikte teknolojinin hızla gelişmesi üniversite kütüphanelerini hem fonksiyonel hem mekânsal açıdan etkilemiştir. Varlıklarını sürdürmek ve araştırmacılara gerekli hizmeti verebilmek için kütüphaneler dijital çağın getirilerine uyum sağlamak durumundadır. Dijitalleşme sonucu bilgi kaynaklarının mekâna bağlılığı ortadan kalktığından dolayı kaynakların depolandığı alanlarda işlevsizlik problemi görülmeye başlanmış ve bu durumun sonucu olarak gelecekte kütüphane binalarının varlığına ihtiyaç olup olmayacağı sorgulanmaya başlanmıştır (Lynch, 2000, s.63; Rasmussen ve Jochumsen, 2009, s. 4). Ancak, kütüphane kullanımıyla ilgili çeşitli alanlarda yapılan çalışmalar, kütüphanelerin alışılagelmiş işlevsel özelliklerindeki değişime veya kayba rağmen kullanıcılar için çalışma ve araştırma söz konusu olduğunda hala vazgeçilmez bir mekân olduğunu ve kullanıcıların kütüphane kullanma eğiliminin arttığını göstermektedir (Rasmussen ve Jochumsen, 2009; TÜİK, 2015). Bu eğilimin artmasındaki sebep, kütüphanelerin fiziksel olanaklarının kullanıcıya sağladığı faydalardır. Örneğin kullanıcılar, kütüphane içerisinde araştırma yaparken daha kolay odaklanmaktadır. Kütüphanede konsantrasyonun sağlanmasında etkili olan sessizlik, çalışma ortamının avantajları vb. birçok imkân bulunmaktadır. 

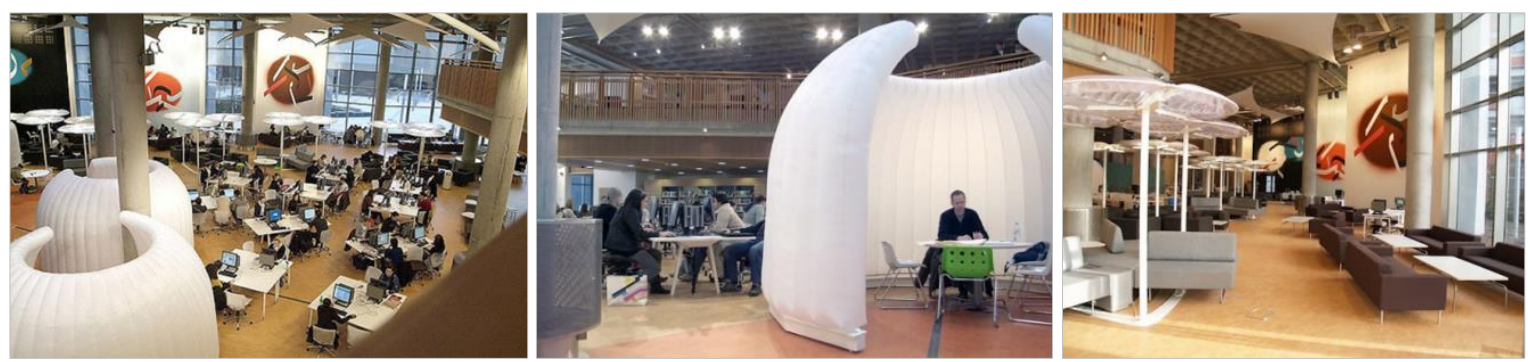

Şekil 1. Glasgow Caledonian Üniversitesi Saltire Merkezinin üçüncü mekân niteliği taşıyan ve farklı çalışma türlerine uygun oturma birimlerini gösteren iç mekânı (Peitx, 2017, s. 10-11)

Dünya üzerinde hem dijitalleşmeye uyum sağlayabilen hem de bu tür fiziksel olanakları iyi bir şekilde karşılayabilmiş yenilikçi mimari örnekler görmek mümkündür. Örneğin; Glasgow Caledonian Üniversitesi Saltire Merkezi, Avrupa'daki birçok açıdan yenilikçi yaklaşımları olan ilk üniversite kütüphanelerindendir (Şekil 1). JISC’in (2006, s. 26-27) raporuna göre kütüphanenin asıl teması esneklik olup; farklı öğrenme ve çalışma tiplerine uygun mekânsal çeşitlilik sunan bir iç mekân organizasyonu geliştirilmiştir. Hollandalı mimarlık bürosu Mecanoo'nun tasarımı olan Delft Üniversitesi Kütüphanesi ise doğal ışı̆̆ kullanımı ve çalışma mekânlarında çeşitliliği kadar iç ve dış mekânıyla kampüste odak noktası oluşturması açısından başarılı bir örnektir (Şekil 2).

RIBA Stirling ödülü alan Will Alsop tasarımı Peckham Kütüphanesi de bina tasarımı ile bütünleşen mekânsal düzenlemesi, aydınlatma ve havalandırmadaki başarılı tasarımı ile binanın enerji gereksinimlerini azaltan önemli bir sürdürülebilir kütüphane örneğidir (Şekil 3).
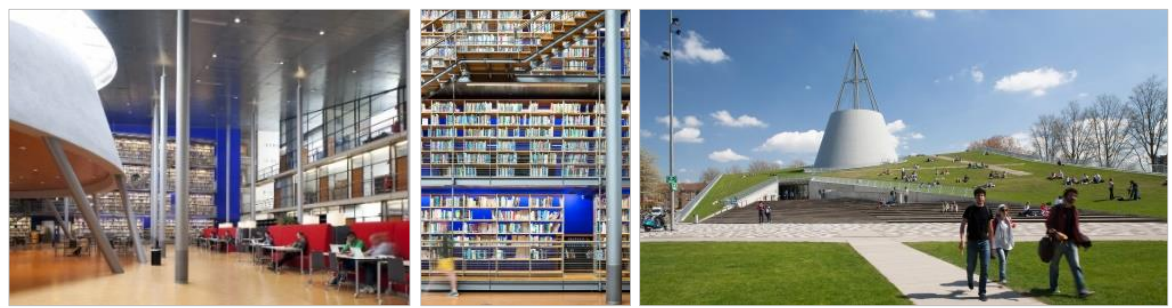

Şekil 2. Delft Üniversitesi Kütüphanesi, iç ve dış mekânı (Mecanoo, t.y.)

Bu örneklerde kullanıcıların memnuniyetleri 5 üzerinden 4,5 ve üstü, ortalama mekânda kalma süreleri 4 saatin üzerindedir (Google popüler saatler, t.y.). Görüldügü üzere kütüphanelerde tasarım ve organizasyonda kullanıcı yararı için imkânları artırmak, onların kütüphane memnuniyetine önemli derecede etki ederek araştırma ve öğrenmede hissedilir artış sağlar.
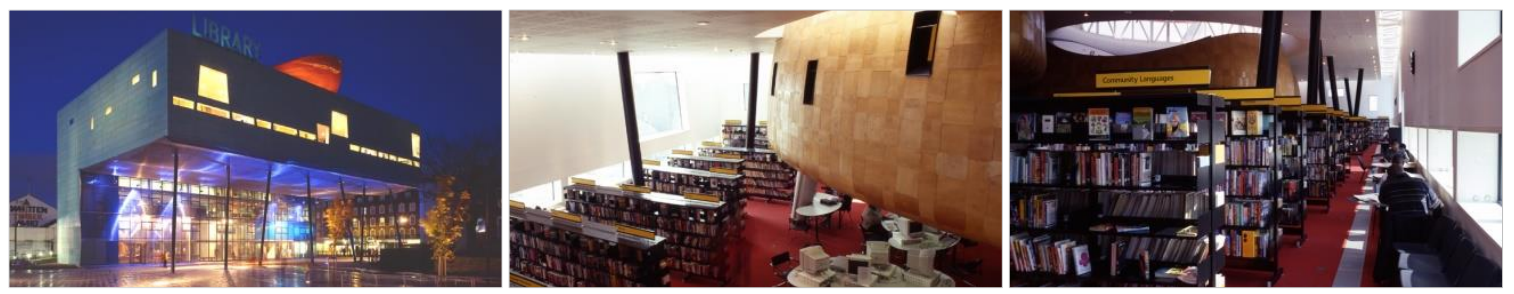

Şekil 3. Peckham Kütüphanesinin dış ve iç mekân fotoğrafları (Archello, t.y.)

Kütüphaneler kullanıcılarının düzenliliği ve ziyaret sıklığına bakıldığında teoride üçüncü mekân olarak algılanabilirler. Oldenburg (1991), birinci mekânı ev, ikinci mekânı iş olarak 
tanımlarken, üçüncü mekân için devamlı bir kullanıcısı olan, ana bir işlevin olduğu, içecek bir şeyler satın alınabilen ve toplumun kullandığı mekânlar tanımını kullanmıştır. Üçüncü mekân, zamanla artan sosyallikten uzaklaşma ve yalnızlaşma sorununa bir çözüm önerisi olarak sunulmaktadır. Mekânsal olarak ev sicaklığına benzerken; cinsiyet, dil, din ve irk fark1 gözetmeksizin eşitliği ile birinci mekânlardan ayrılır. Kafe, kuaför gibi mekânlar da bu kategoriye dâhildir (Demir, 2019). Kullanıcıların bu tarz mekânları sosyalleşmek ve rahatlamak için daha çok tercih ettikleri günlük hayatta da gözlenmektedir. Aabø ve Audunson (2012), kütüphanelerin de üçüncü mekân teorisine büyük çoğunlukla dâhil olduğunu tespit etmiştir.

Kütüphane yapılarının fiziksel olanakları, mekânsal nitelikleri ile birebir bağlantılıdır. Bu mekânsal niteliklerin ise kütüphanelerin sadece 1s1, nem, ses ve aydınlık düzeyi gibi yap1 fiziksel nitelikleri ile değil aynı zamanda mimarileri ve iç tasarımlarıyla doğrudan bağlantılı olması beklenir. Daha iyi tasarlanmış, estetik ve fonksiyonel olarak nitelikli bir mimari mekân, kütüphane fonksiyonlarının yeni nesil ihtiyaçlarını karşılamak için yeni çözümler sunacaktır. Yurt dışındaki örneklere bakıldığında iyi tasarlanmış çağdaş kütüphane yapıları, fiziksel imkânları ile cazip odak noktaları oluşturmaktadır. Ülkemizde birçok üniversite kampüsünde genellikle bağımsız bir bina olarak tasarlanan, kapsamlı kütüphane yapıları bulunmaktadır. Fakat bu kütüphanelerin birçoğu erişilebilirlik, fiziksel imkân ve iç mimari düzenlemeler açısından yurt dışındaki örneklere göre yetersiz kalmaktadır. Yurt dışındaki kütüphane kullanımlarının yüksekliği ve kütüphanelerin kampüs hayatında üstlendiği merkezi rolün ülkemizde aynı oranda gerçekleşmemesinde kütüphane mekânının yetersiz mimari ve iç mimari tasarımının etkisi olabilir.

\section{Akdeniz Üniversitesi Merkez, Kütüphanesi}

Akdeniz Üniversitesi kampüsünde bir adet merkezi kütüphane binası vardır. Bazı fakültelerin içerisinde kendi özel kitaplıkları bulunmaktadır; ancak kapsamlı kütüphane şeklinde olmadığı ve genellikle koleksiyon açısından yetersiz ve tek yönlü kaldığ 1 için yoğunlukla üniversitenin merkez kütüphanesi kullanılmaktadır. Zemin dâhil üç katlı bir yapısı olan merkezi kütüphane (Şekil 4) konum itibariyle kampüsün doğusunda bulunmaktadır. Erişim çoğunlukla özel araçla ve yaya olarak sağlanmaktadır. Dikdörtgen planlı yapı, merkezde galeri bulunacak şekilde kurgulanmış; çalışma alanları ve kitaplıklar çeperler ${ }^{1}$ doğrultusunda konumlanmıştır. Doğal aydınlatma dış duvardaki pencereler ve merkezdeki galeriden sağlanmaktadır. İç mekân havalandırması klimalar ve merkezi iklimlendirme sistemi ile sağlanırken, doğal havalandırma için özel bir sistem bulunmamaktadır. Çalışma alanlarının kurgusu, bütünleşik mekânsal bir tasarımdan ziyade basit masa ve raflardan oluşan mobilyalarla düzenlenmiştir. Bunların düzenlenmesi sırasında ise ortak çalışma alanlarına özel bölümler oluşturulmamış; bireysel çalışma masalarının yanına daha büyük masalar konumlandırılmıştır.

Kullanıcılarla yüz yüze yapılan görüşmelerde, kütüphanenin en büyük probleminin çalışma alanı yetersizliği ve gürültü olduğu tespit edilmiştir. Doğal havalandırmanın ve çalışma alanlarının aydınlık seviyesinin yetersizliği de birçok kullanıcı tarafından fiziksel koşullarla ilgili eleştiri olarak belirtilmiştir. Bu eksiklerin sonucu olarak kütüphanede kalma süresi,

\footnotetext{
${ }^{1}$ Çeper kavramı, iç ve dış mekan arasında basit bir ayraç görevinin ötesinde planın merkezinden uzak, dış cephelerine paralel, kenarlardaki lineer alanları tanımlamaktadır.
} 
yukarıda anlatılan mimari nitelikleri daha iyi olan diğer kütüphanelere göre $\% 23$ daha az olup, ortalama 3,5 saattir (Google Popüler Saatler, t.y.).
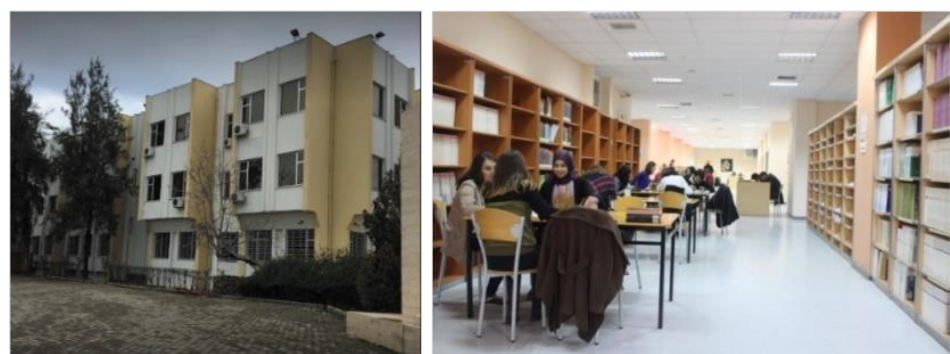

Sekil 4. Sol: Akdeniz Üniversitesi Merkez Kütüphanesi Binası (Google Fotoğraflar, t.y.), Sağ: Akdeniz Üniversitesi Merkezi Kütüphanesi Zemin Katı (Akdeniz Kampüs Haber, 2016)

Üniversite kütüphanelerinin değerlendirmesinde kullanıcı talepleri en önemli girdidir. Anket yöntemiyle veri toplama ve analiz sonuçlarıyla değerlendirme, bu taleplerin tespitindeki yöntemlerden biridir. Li, Wu ve Su (2018) tarafindan South China University of Technology'de (SCUT)'de yapılan bir çalışmada uygulanan anketin ülkemize uyarlanmasıyla yapılan bu çalışmanın amacı, Akdeniz Üniversitesi Merkez Kütüphanesi kullanıcılarının taleplerinin ortaya çıkarılması, elde edilen verilerin değerlendirilmesi ve günümüzde üniversite kütüphanelerinin iyileştirilmesi için gerekli olan somut verilerin belirlenmesidir. Bu kapsamda, kütüphanenin fonksiyonel, yapısal ve fiziksel niteliklerinin yanı sıra mekânsal tasarımının da kullanıcıların memnuniyetine olan etkisi araştırılmıştır.

Üniversite kütüphanelerinin niteliklerini ölçme ve hizmet kalitesini değerlendirme hususundaki standartlar için, Amerikan Üniversite ve Araştırma Kütüphaneleri Derneğinin (ACRL) uzun yıllardır yaptığı çalışmalar bu konuda önem taşımaktadır (Polat ve Odabaş, 2011, s.44). Bu derneğin kütüphanelerdeki personel, bütçe, fiziksel ortam ve koşulları, derme ${ }^{2}$ geliştirme, kaynak alımı ve sunumuna yönelik standartları bulunmaktadır. Mimari tasarım ile bağlantılı olarak fiziksel ortam ve koşullarına bakıldığında standartlar şu şekildedir: kullanıcı ihtiyaçlarını karşılamaya yeten ve kullanıcıya uygun olan alanlara sahip olması, iklimlendirme koşullarının uygunluğu, aydınlatma yeterliliği, masa ve sandalye yeterliliği, personel alanlarının yeterliliği, büro malzemelerinin yeterliliği, çalışma alanlarının kullanıcı performansını artıracak nitelikte bir tasarımda olması, çalışma alanlarının ergonomik uygunluğu, depo alanlarının mevcut kapasiteyi ve gelecekteki artışı karşılayacak düzeyde olması ve son olarak teknolojik altyap1 yeterliliğidir (Polat ve Odabaş, 2011, s.47-48). Li, Wu ve Su'nun (2018) çalışmasındaki anketin uyarlanmasıyla yapılan bu çalışmada kullanılan parametreler ile bu standartlar arasında uyum gözlenmektedir.

Ulusal ve uluslararası literatürde kütüphanelerin fiziksel nitelikleri ve mekânsal tasarımıyla ilgili çalışmalar bulunmaktadır. Örneğin; uluslararası literatürde kütüphanelerin fiziksel nitelikleri araştırıldığında gürültünün, kullanıcı zihninin çalışma kapasitesini ve performansını düşürdüğü (Banbury ve Berry, 1998); aydınlatmanın, insanların davranışlarını değiştirdiğini ve bu davranış değişikliğinin çalışma verimliliği etkilediğini (Groth, 2007) ve iç ortamın düşük hava kalitesinin de kullanıcıların öğrenme verimliliğini olumsuz etkileyebileceği tespit edilmiştir (Choi, Guerin, Kim, Brigham ve Bauer, 2013-2014; Lee, Mui, Wong ve

\footnotetext{
${ }^{2}$ Derme sözcüğü Türk Dil Kurumu sözlüklerinde "aynı türden bir araya getirilmiş şeylerin hepsi, koleksiyon” olarak tanımlanır (Türk Dil Kurumu, 1988, s.361).
} 
Cheung, 2012). Kütüphanedeki genel araştırma ortamının yanı sıra, fiziksel olanakların erişilebilirliğinin de (Castilla, Llinares, Bravo ve Blanca, 2017) fiziksel nitelikler arasında önemli olduğu gözlenmiştir ( $\mathrm{Li}, \mathrm{Wu}$ ve Su, 2018, s.727). Bunun yanı sıra Hohmann (2006), çalışmasında değişen ihtiyaçlarla birlikte kütüphanelerdeki yeni planlama ilkelerine değinmiş ve zamanın getirilerine uyum sağlayabilmesi için kütüphanelerin bilgi kaynağı, mekânsal organizasyon, akustik, havalandırma vb. birçok özellik açısından nasıl doğru bir biçimde şekillenmesi gerektiğini anlatmıştır. Head (2016), çalışmasında kütüphane kullanıcıları ve mimarlar ile yaptığı araştırma ile kütüphanelerin planlama ve uygulama süreçlerinde nelere dikkat edilmesi gerektiğine birçok parametre ve ölçüt belirleyerek değinmiştir. Leighton ve Weber (1999), kitaplarında akademik ve araştırma kütüphanelerinin vaziyet planı ölçeğinden iç mekân kriterlerine kadar bütün planlama ve tasarım aşamalarını incelemişlerdir. Fraley ve Carol (1990), kitaplarında kütüphane mekânlarının yeniden değerlendirilmesi ve doğru planlama ve organizasyon ile alandan en iyi şekilde yararlanma teknikleri sunmaktadır. Ulusal literatüre bakıldığında ise Aydoğan (2017), tezinde üniversite kütüphanelerinin mekân morfolojileri ve mimari programlarının kullanıcıya sunduğu esnekliği incelemiş, bu doğrultuda İstanbul'daki beş üniversite kütüphanesini, mekânın işleyiş şeması ve mekân morfolojisinin kullanıcıdaki mekân kullanımına etkisi üzerinden analiz etmiştir. Küçükcan (2005), tezinde üniversite kütüphanelerini yapı biyolojisi açısından incelemiş, tasarıma ve fiziksel faktörlere bağlı sağlık sorunlarını araştırmış ve bir üniversite kütüphanesi tasarımının nasıl olması gerektiğini açıklamıştır. Küçükcan, Balanlı, Öztürk ve Vural (2007) yaptıkları çalışmada, Yıldız Teknik Üniversitesi Merkez Kütüphanesinin kullanıcılarının görüşleri ile kütüphanenin fiziksel niteliklerini ve kullanıcıların endişelerini tespit etmişler ve bu bağlamda değerlendirmeler yapmışlardır. Altuğ (2019), tezinde seçtiği 15 üniversiteyi kullanıcı sayısı, mekânsal nitelikleri, kitap sayısı vb. özelliklerine göre değerlendirmiş ve bu değerlendirmeler doğrultusunda kütüphanelerin günümüzün mekân ihtiyaçlarına cevap vermesi hususunda önerilerde bulunmuştur. Kuru ve Türkyılmaz (2019), yaptıkları çalışmada Bahçeşehir Üniversitesi kütüphane binasının fiziksel olanaklarını, gözlem ve ölçüm gibi tekniklerin yanı sıra personel ile anket yaparak da değerlendirmiş ve donatıların ergonomik koşulları sağlamasına rağmen mekânsal organizasyonda ergonomik ölçütlere dikkat edilmediği sonucuna varmışlardır.

\section{Yöntem}

$\mathrm{Bu}$ araştırmada kullanılacak yöntemin ilk aşaması, literatür taramasına dayalı oluşturulan anket ile kullanıcı görüşlerinin elde edilmesidir. Elde edilen veriler, birçok istatistik analizin yapıldığ 1 SPSS programı aracılığı ile anlamlı sayısal verilere çevrilmiş, daha sonra bu verilerin doğruluğunu ölçmek ve tek bir model üzerinden yorumlamak için $\mathrm{AMOS}^{3}$ programında analiz edilmiştir. Analizlerden elde edilen sonuçlar ile mimari açıdan değerlendirme yapılmıştır. Bu yöntem, uzun süreli gözlemler yerine anket çalışmaları ile durum tespiti yapmaya yöneliktir.

$\mathrm{Bu}$ çalışmada kullanılan yöntemin yanı sıra, benzer durumlarda etkin bir araç olarak Kullanım Sürecinde Değerlendirme (KSD) (Post occupancy evaluation - POE) yöntemi de kullanılmaktadır. Uygulanan yönteme göre daha farklı bir analiz yolu (örneğin çok aşamalı

\footnotetext{
${ }^{3}$ IBM SPSS AMOS; regresyon, faktör analizi ve birçok analiz yöntemlerini genişleterek araştırmalara yardımcı olan yapısal eşitlik modellemesi yazılımıdır (IBM, t.y.).
} 
skala) izleyen KSD, kullanıcılar için tasarlanan çevrenin kullanıcı yararında geliştirilmesi için yapılması gereken şeylerin, gözlem, görüşme ve çeşitli yöntemlerin kullanılması ile keşfedildiği süreçtir (Göktekin, 2002, s.3). KSD modeline benzer şekilde bu istatistik çalışmasının hazırlık ve ölçek uyarlama aşamalarında da gözlem ve derinlemesine görüşmeler yapılmıştır.

Çalışma kapsamında uygulanan anket için 2018 yılında Hin Li ve arkadaşları tarafından geliştirilen kütüphane değerlendirme ölçeği kullanılmıştır. Bu ölçek, konu üzerine önceden yapılmış herhangi bir çalışma olmamasından ötürü, kullanıcıların öğrenme memnuniyetini etkileyebilecek çevresel faktörleri tespit etmek için literatür taramasına dayalı bir değerlendirme sistemi oluşturmuştur. Böylece henüz ölçek hazırlanma aşamasında değişkenlerin tespiti sağlanmıştır. Ölçeğin yerel koşullara uyarlanması sırasında kütüphanenin erişilebilirliği ile ilgili soru (bkz. Ek-1), Akdeniz Üniversitesi kampüs yapılanmasından ötürü, açık uçlu soruya çevrilerek değerlendirilmiştir. Şekil 5'te görüldüğü üzere, Akdeniz Üniversitesi kampüsündeki tek kütüphane kampüsün doğu tarafında konumlandırılmıştır ve batı tarafında kalan Edebiyat, Eğitim, İletişim, ilahiyat gibi fakültelere yaklaşık 20 dakikalık yürüme mesafesi ile oldukça uzak kalmaktadır. Kampüs içerisinde düzenli olarak dolaşan servisler vardır. Ancak yine de kütüphaneye en yakın durak 7 dakika yürüme mesafesindedir. Yapının yakın çevresinde ise Tıp, Mimarlık, Diş Hekimliği ve Hukuk Fakülteleri bulunmaktadir.

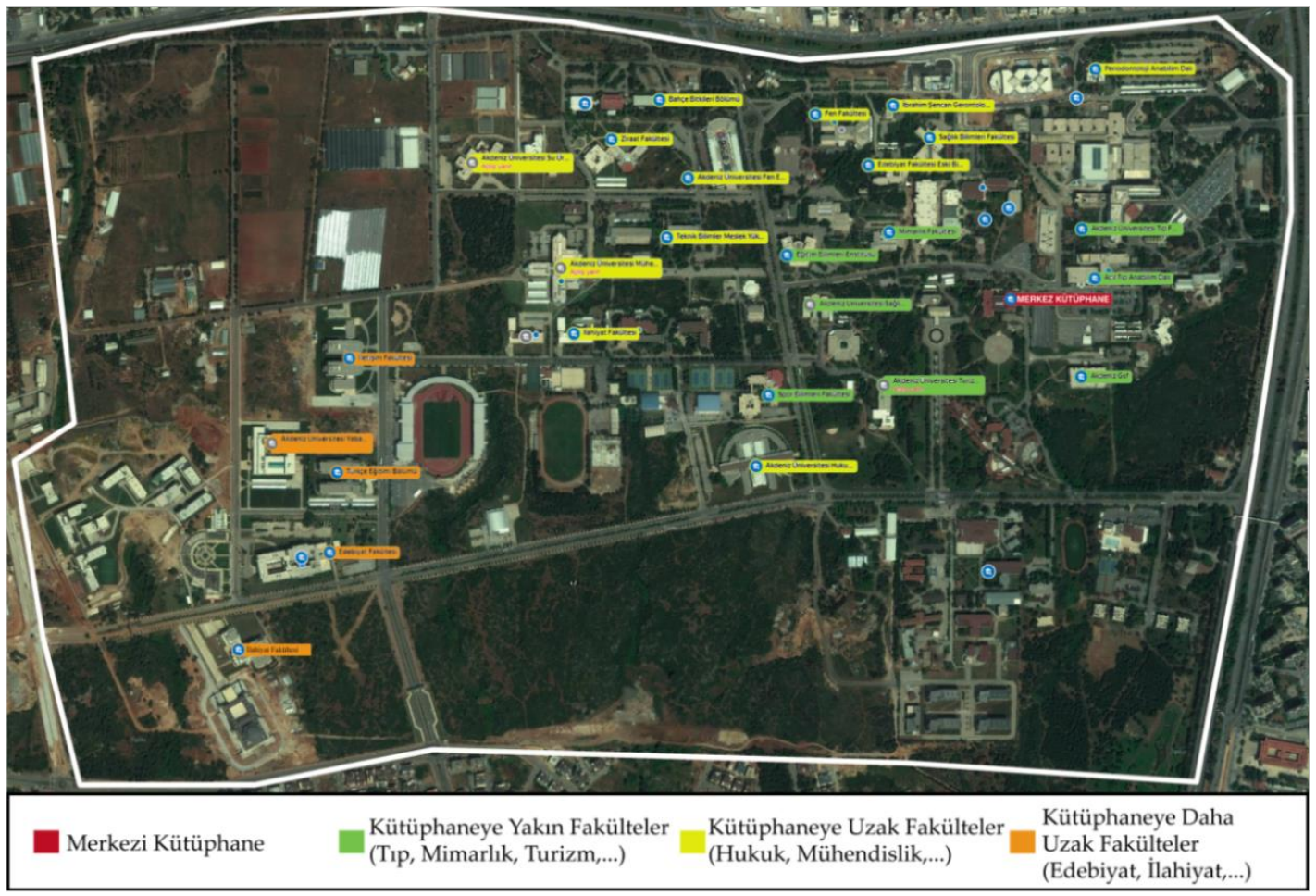

Şekil 5. Akdeniz Üniversitesi Merkez Kütüphanesinin kampüs içerisindeki konumu

Örnek ölçeğin oluşturulması sırasında literatür taraması yoluyla kütüphane ziyaretinde ve öğrenim durumunda etkili olan altı ana başlık belirlenmiştir. Belirlenen altı faktörün alt başlıkları bağımsız değişkenleri oluşturmakla birlikte, bu başlıklar; akustik (1), aydınlatma (2), hava kalitesi (3), çalışma olanakları (4), çalışma alanı kurgusu (5) ve ulaşılabilirliktir (6) (Li, $\mathrm{Wu}$ ve Su, 2018, s. 728). Everaert, Opdecam ve Maussen’e göre (2017) bağımlı değişkenleri 
oluşturan faktörlerden ziyaret süresinin alt başl1kları ziyaret sıklığı ve kütüphanede geçirilen süre olarak; öğrenim durumunun ise, öğrenim verimliliği ve konsantrasyon olarak ayrılmaktadır (aktaran Li, Wu ve Su, 2018, s.728). Hazırlanan anket, kişisel soruları barındıran demografik değerler dışında kalan kısımlar kullanıcıların kütüphane memnuniyetini ölçen yedili Likert ölçeği ile hazırlanan sorulardan meydana gelmiştir. Çıkarılan alt başlıklar (bağımlı ve bağımsız değişkenler) anketin bu kısmını oluşturmaktadır. Belirlenen bağımlı ve bağımsız değişkenlere sırasıyla güvenilirlik analizi ve faktör analizi yapılmış, daha sonra elde edilen veriler yapısal eşitlik modellemesine (YEM) aktarılarak son model üzerinden nedensellik ilişkileri tartışılmıştır.

74.000 lisans ve lisansüstü öğrenci kapasiteli Akdeniz Üniversitesi'nde anketin örneklem büyüklüğü \%95 güven aralığı (\%5'lik hata payı) ile 383 olarak hesaplanmıştır. ${ }^{4}$ Anket 392 katılımcıya uygulanmıştır ve SPSS programına verilerin girilmesi ile 383 sonuç analizler için uygun görülmüştür. ${ }^{5}$

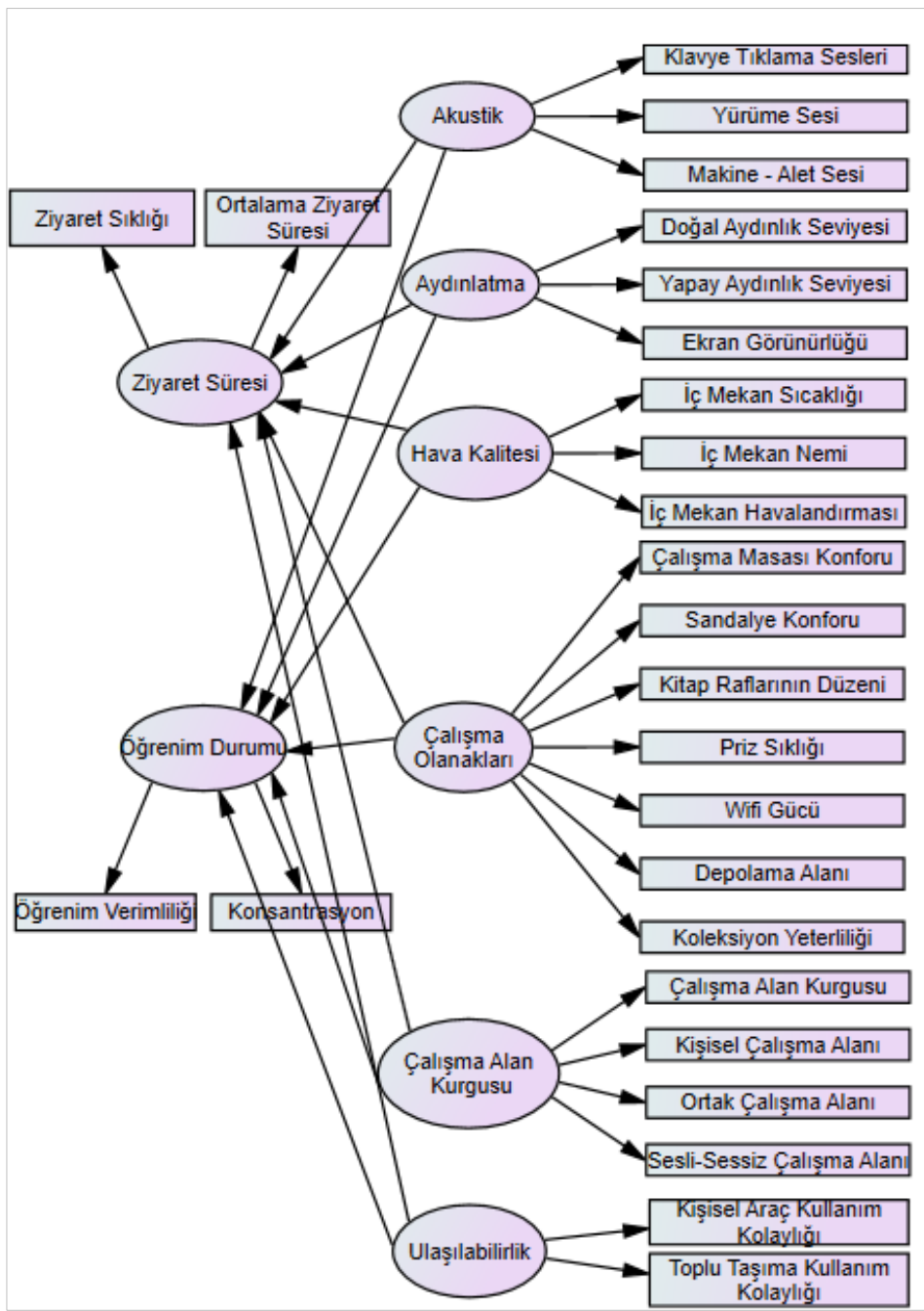

Şekil 6. Oluşturulan ilk yapısal eşitlik modellemesi ve ön görülen çalışma sistemi

\footnotetext{
${ }^{4}$ Örneklem büyüklüğünü belirlemek için yararlanılan kaynak için bkz. https://www.surveymonkey.com/mp/sample-sizecalculator/

${ }^{5}$ Faktör analizinden önce, ankete verilen yanıtların tutarlılığı ölçmek amacıyla güvenilirlik analizi yapılmış, Cronbach's alpha değeri 0,9 bulunmuştur. "Katsayının 0.7 ve üstü bulunması durumunda ölçeğin güvenirliği iyi olarak kabul edilir." (Kılıç, 2016, s. 47)
} 
Literatür taraması ile tespit edilen 22 değişken bağımsız değişkenlerdir ve altı temel faktör altında gruplanmıştır. Bu değişkenler bağımlı değişkenler olan ziyaret süresi ve öğrenim durumunu etkilemektedir. Örneğin, mekân içerisindeki gürültü seviyesi, kullanıcının konsantre olmasını zorlaştırır ve öğrenim verimliliğini azaltır. Öte yandan erişimdeki zorluk ziyaret sıklığını azaltabilir. Bağımsız değişkenler bağımlı değişkenleri etkiler. Faktör analizi yapmadan önce, değişkenler ortak özellikleri altında analiz sonuçlarında çıkması ön görülen biçimde toplanmış ve Şekil 6'daki ilk yapısal eşitlik modellemesi oluşturulmuştur.

\section{Bağımlı ve Bağımsız Değişkenler için Keşfedici ve Doğrulayıcı Faktör Analizleri}

Şekil 6'da oluşturulan model, verilerin değerlendirmesi sonucu yeniden sorgulanmış ve bağımsız değişkenler için keşfedici faktör analizi ile bir dizi istatistik işlemden ${ }^{6}$ sonra uygulanmıştır. Model oluşturulurken kütüphane kullanımına etkili olduğu düşünülerek yapılandırılan modelin, ilk tahmin edilen faktörlerinin bazılarının kullanıcılar için hipotezde önerildiği gibi etkili olmadığı analiz edilmiştir. Böylece bazı faktörler modelden çıkarılmıştır. İlk analizden sonra faktör çıkarması yapılırken ulaşılabilirliğin değişkenleri tamamen farklı faktörlere yüklenmiş olduğu için öncelikle ulaşılabilirlik faktörü tamamen çıkarılmıştır. Daha sonra her bir aşama için yapılan analizlerde farklılık gösteren yükler de sırasıyla (ekran görünürlüğü, kişisel çalışma alanı yeterliliği ve çalışma masası konforu) çıkarılmış ve analiz tekrarlanmıştır. $\mathrm{Bu}$ faktör çıkarmalar ilk aşama için kullanıcılar açısından önemli olan değişkenleri tespit etmek için yapılmıştır. Çıkarılan ulaşılabilirlik, ekran görünürlüğü, kişisel çalışma alanı yeterliliği ve çalışma masası konforu faktörlerinin Akdeniz Üniversitesi Kütüphanesi kullanıcıları için bir problem olmadığı gözlenmektedir.

Akdeniz Üniversitesi Merkez Kütüphanesinin konumu, kampüs yapılaşması ve toplu taşıma olanakları, birçok fakülte için kütüphaneye ulaşımı zorlaştırmaktadır. Kütüphaneye direkt olarak giden servis ya da toplu taşıma aracı bulunmadığından kullanıcıların özel araçlarıyla ya da yaya olarak kütüphaneye ulaşması gerekmektedir. Bazı fakülteler kendi binalarında kütüphane barındırmaktadır; fakat birçok fakültenin kütüphane birimi yetersiz kalabilmekte veya fakülte içerisinde kütüphane bulunmamaktadır. Kullanıcıların ihtiyacını karşılayacak başka bir kütüphane binası olmaması nedeniyle Merkez Kütüphane kullanıcıları için ulaşılabilirlik bir tercih faktörü değildir. Bu sebeple, 'ulaşım' kullanıcılar için bir faktör olmaktan direkt olarak çıkmaktadır. Yapılan son döndürme matrisi ile (bkz. Tablo 1) Akdeniz Üniversitesi için 22 değişken kullanıcı için önemli olan 17 değişkene inmiş; ilk modellemede (bkz. Şekil 6) ön görülen altı faktör, çalışma olanakları ve çalışma kurgusunun tek faktöre yüklenişi ve ulaşılabilirlik faktörünün tamamen kaldırılması ile dörde inmiştir.

\footnotetext{
${ }^{6} \mathrm{KMO}$ ve Barlett Testi ilk aşama için uygulanmıştır. Bağımsız değişkenler için uygulanan test 0,841 sonuçla örneklemin analiz için yeterli olduğunu göstermektedir. Daha sonra faktörleri daha kolay yorumlayabilmek için döndürme işlemi uygulanmış; birden fazla faktöre çok yakın faktör yükleriyle yüklenen değişkenler çıkarılmıştır. Bu değerlendirme sırasında öz değeri bir ve daha büyük olan faktörler önemli faktörler olarak alındığından Akdeniz Üniversitesi Merkez Kütüphanesi için yapılan anketin verileri için analizde öz değeri biri geçen dört faktör bulunmuştur.
} 
Tablo 1

Bağımsız değişkenler için yapılan son döndürülmüş bileşen matrisi

\begin{tabular}{|c|c|c|c|c|}
\hline Faktörler & Değişkenler & & ör Yük Değeri & \\
\hline & & & & \\
\hline Akustik & T1klama Sesleri & & 0,7 & \\
\hline & Yürüme Sesi & & 0,7 & Faktör1 \\
\hline & Makine-Alet Sesleri & & 0,7 & \\
\hline Aydinlatma & Doğal Aydınlatma & & 0,8 & \\
\hline & Yapay Aydınlatma & & 0,8 & Faktör2 \\
\hline & Ekran Görünürlüğü & - & - & \\
\hline Hava Kalitesi & İç Mekân Sicaklığ1 & & 0,8 & \\
\hline & İç Mekân Nemi & & 0,8 & Faktör3 \\
\hline & İç Mekân Havalandırması & & 0,6 & \\
\hline Mekân Olanakları & Çalışma Masası Konforu & - & - & \\
\hline & Sandalye Konforu & & 0,6 & \\
\hline & Kitap Raflarının Düzeni & & 0,6 & \\
\hline & Priz S1klı̆̆ 1 & & 0,5 & Faktör4 \\
\hline & Wifi Gücü & & 0,5 & \\
\hline & Depolama Alanı & & 0,7 & \\
\hline & Kütüphane Koleksiyonu & & 0,6 & \\
\hline Çalışma Alanı Kurgusu & Çalışma Alanı Kurgusu & & 0,6 & \\
\hline & Kişisel Çalışma Alanı & - & - & \\
\hline & Ortak Çalışma Alanı & & 0,6 & \\
\hline & Sesli Sessiz Çalışma Alanı & & 0,6 & \\
\hline Ulaşım & Kişisel Araç ile Ulaşım & 一 & - & \\
\hline & Toplu Taşıma ile Ulaşım & - & - & \\
\hline
\end{tabular}

Not. Bir değişkenin faktör yükünde, "0.60 ve üstü yük değeri yüksek; $0.30-0.59$ arası yük değeri orta düzeyde büyüklükler olarak tanımlanabilir ve değiş̧ken çıkartmada dikkate alınır” (Büyüköztürk, 2002, s.474). Bu çalı̧̧mada verilerin analiz sonunda çıkan faktör yükleri göz önüne alınarak, 0.4 değeri faktör çıkarmada sınır olarak alınmıștır.

Analiz sonuçlarına göre mekân ve olanakların, çalışma alanı kurgusuyla birleşmesi kullanıcılara göre bu değişkenler arasında bir bağlantı ve yakınlık olduğunu göstermektedir. Anlaşılmaktadır ki kullanıcılara göre kütüphanenin tasarımı ve kütüphanenin sağladığ1 imkânlar arasında büyük bir fark görülmemektedir. Bu durum kullanıcıların çağdaş mimarlık hakkındaki bilgilerinin sorgulanmasını gerektirir (Önemli çăgdaş örnekleri biliyorlar mı? Başka kütüphane yapılarını deneyimlemişler mi? vb.); bununla birlikte kullanıcıların kampüs içerisinde başka bir kütüphane alternatifi olmadığı da göz önünde bulundurulmalıdır. Bağımlı değişkenlere uygulanan keşfedici faktör analizi ve döndürme işlemlerinde ${ }^{7}$ ise faktör sayısı, ön görülen sayı ile aynı çıkmış ve değişkenlerin faktörlerle ilişkisi öngörülen ilk modelleme ile eşleşmiştir. Haftalık ziyaret sıklığı ve ziyaret edildiğinde geçirilen sürenin ziyaret faktörünü; konsantrasyon ve öğrenim verimliliğinin ise öğrenebilme durumu faktörünü etkilediği bulunmuştur. Keşfedici faktör analizlerinden sonra her iki gruba da Doğrulayıcı Faktör Analizi ${ }^{8}$ uygulanmış; Tablo 2'de görüldüğü üzere bağımlı ve bağımsız değişkenler uygunluk değerlerine uyum sağladığı için herhangi bir faktör silinmesi yapılmamıştır.

\footnotetext{
${ }^{7}$ Bağımlı değişkenlerin faktör analizine uygunluğunun tespit edilmesi için KMO ve Barlett testi yapılmış ve 0,55 ile minimum olan 0,5 değerin üstünde çıkmıştır.

${ }^{8}$ Doğrulayıcı faktör analizi, "genellikle ölçek geliştirme ve geçerlilik analizlerinde kullanılmakta veya önceden belirlenmiş bir yapının doğrulanmasını amaçlamaktadır." (Yaşlıŏlu, 2017, s. 78)
} 
Tablo 2

Doğrulayıcı faktör analizi sonucu bağımlı ve bağımsız değişkenlerin uyum iyiliği indeksleri ${ }^{9}$

\begin{tabular}{lrrr}
\hline İndeksler & Uygunluk aralığ & \multicolumn{2}{c}{ Değer / Uygunluk } \\
\cline { 3 - 4 } & & Bağımlı değişken & Bağımsı değişken \\
\hline CMIN/DFI & $<3.00$ & 0,639 / Evet & 2,2222 / Evet \\
RMSEA & $<0,08$ & $0,000 /$ Evet & 0,057 / Evet \\
GFI & $>0,90$ & 0,999 / Evet & 0,929 / Evet \\
AGFI & $>0,90$ & $0,992 /$ Evet & $0,903 /$ Evet \\
PGFI & $>0,50$ & $0,100 /$ Hayır & $0,686 /$ Evet \\
\hline
\end{tabular}

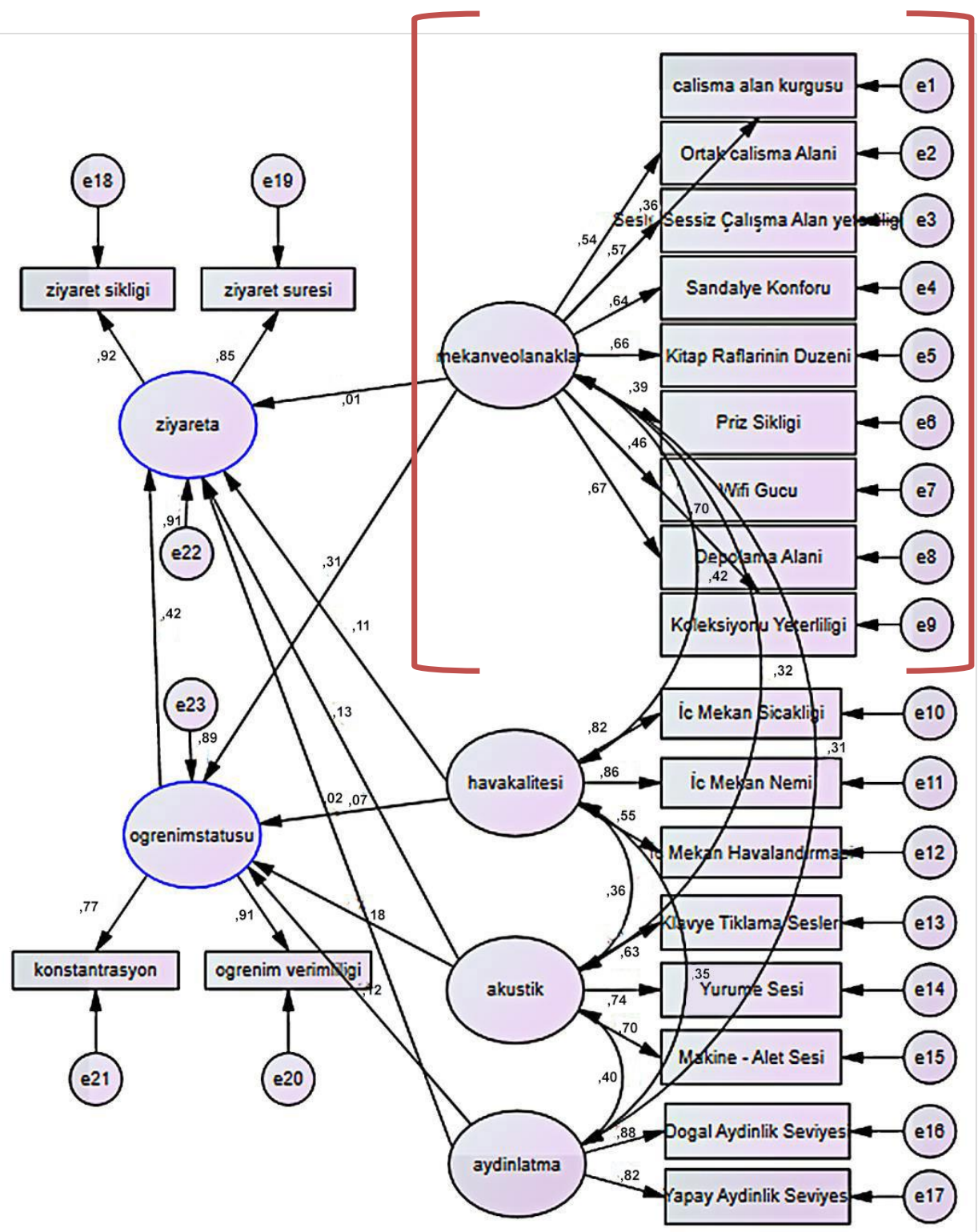

Şekil 7. Doğrulayıcı Faktör Analizi (DFA) sonrası birleştirilmiş ilk Yapısal Eşitlik Modeli (YEM) Not. Analizler sonucu mekân ve olanakların endekslere uyumsuzluk gösterdiği tespit edilmiştir. Son modelde bu faktör çıkarılmıştır.

\footnotetext{
${ }^{9}$ Tablo 2 ve 3 ’teki uyum indeksleri Dursun ve Kocagöz'ün (2010, s. 15) çalışmasındaki değerler üzerinden yapılmıştır.
} 


\section{Yol Analizi}

Son aşama olarak değişkenler arasındaki nedensellik ilişkisinin analizler üzerinden incelenebilmesi için, elde edilen son bağımlı ve bağımsız değişkenler, AMOS programında birleştirilerek modellenmiştir. Şekil 7'de görülen birleştirilmiş ilk modellemede, veri sonuçlarının yapılan modelle uygunluk derecesinin tespiti için uygunluk değerlerine bakılmıştır. İstatistiksel olarak anlamlı sonuç vermediği için ilk modelde uyumsuzluk gösteren 'mekân kurgusu ve olanakları' son modelden çıkarılmıştır ${ }^{10}$. Önceden de belirtildiği üzere tasarım ve imkânlar faktörünün birleşmesi ve sonuçta faktörlükten çıkması, kullanıcıların nitelikli kütüphane mimarisi ve çağdaş kütüphane örnekleri hakkında fikir sahibi olup olmadığını sorgulatmakta; ayrıca Akdeniz Üniversitesi kampüsü içerisinde gidebilecekleri başka bir kütüphane olmadığı için böyle bir sonuç elde edildiğini düşündürmektedir. Bu durum analizlerin değerlendirilmesi başlığında ayrıca tartışılmıştır.

Mekân kurgusu ve olanakları faktörün çıkarılması ile model üzerinden analiz tekrarlanmış ve oluşturulan son modelin, istatistiksel olarak verilen uygunluk aralıklarına uyum sağladığı tespit edilmiştir. Anlaşılmaktadır ki; analiz sonucunda akustik, aydınlatma, hava kalitesi ve öğrenebilme durumu faktörlerinin Akdeniz Üniversitesi Merkezi Kütüphanesinde ziyareti etkileyen ana faktörler olduğu tespit edilmiştir. Durumdan gözlenebileceği üzere, bağımlı ve bağımsız değişkenler kendi içlerinde iyi bir korelasyon oluştursa da; yol analizi ile aralarında oluşan nedensellik ilişkilerinin sonuçları değiştirebileceği gözlenmektedir.

\section{Bulgular}

383 katılımcıya yapılan anketin demografik sonuçları şu şekildedir: 383 anket katılımcısının 247'sini erkek ve 136'sını kadın oluşturmaktadır. Yaş skalasına bakıldığında çoğunluğu 20, 21, 22 ve 23 yaşındakiler oluşturmaktadır. Öğrenim düzeyine bakıldığında ise lisans, yüksek lisans ve doktora öğrencileri kütüphaneyi ziyaret etmekte; özellikle lisans 2. ve 3. Sınıflar çoğunluğu oluşturmaktadır.

Analiz sonuçlarından, Akdeniz Üniversitesi Kütüphanesinin ziyaret süresine ve sıklığına etki eden faktörler; mekânın akustik, aydınlatma ve hava kalitesi ile kullanıcıların öğrenim durumu olarak tespit edilmiştir. Mimari tasarım ölçütleri düşünüldüğünde, kütüphane tasarımında Akdeniz Üniversitesi öğrencilerinin yapı fiziği faktörlerini, mekânsal kurgu ve estetik niteliklerden daha önemli gördüğü ortaya çıkmaktadır. Çalışmanın başlangıcında kütüphane kullanımına etki edeceği ön görülen altı faktörün veri analizleri sonucunda değişmesinin sebebi, kullanıcıların öncelikleri ve tercihleridir.

Tablo 3

Son yapılan yapısal eşitlik modellemesi uyum iyiliği indeksleri

\begin{tabular}{lrr}
\hline İndeksler & Uygunluk aralı̆̆ & Değer/Uygunluk \\
\hline CMIN/DFI & $<3.00$ & $2,303 /$ Evet \\
RMSEA & $<0,08$ & $0,058 /$ Evet \\
GFI & $>0,90$ & $0,955 /$ Evet \\
AGFI & $>0,90$ & $0,923 /$ Evet \\
PGFI & $>0,50$ & $0,563 /$ Evet \\
\hline
\end{tabular}

\footnotetext{
10 “İstatistiksel anlamlılığın (statistical significance) varlığının ve varsa da var olan farklılığın kanıtının düzeyinin
} belirlenmesi amacı ile p değerine bakılır." (Kul, 2014). 
Tablo 4

Son yapılan yapısal eşitlik modellemesi sonucu değişkenler arasında hesaplanan iliş̧ki katsayıları

\begin{tabular}{|c|c|c|c|c|}
\hline Yol & $\begin{array}{l}\text { Standardize edilmiş } \\
\text { regresyon ağırlığ }\end{array}$ & S.E. & C.R. & $\mathrm{p}$ \\
\hline Öğrenim Durumu $\leftarrow$ Akustik & 0,245 & 0,094 & 2,605 & 0,009 \\
\hline Öğrenim Durumu $<$ Aydınlatma & 0,268 & 0,074 & 3,599 & 0,001 \\
\hline Ziyaret Süresi $\leftarrow$ Hava Kalitesi & 0,181 & 0,105 & 1,729 & 0,084 \\
\hline Ziyaret Süresi $\leftarrow$ Akustik & 0,257 & 0,133 & 1,931 & 0,053 \\
\hline Ziyaret Süresi $\leftarrow$ Öğrenim Durumu & 0,592 & 0,107 & 5,539 & 0,001 \\
\hline
\end{tabular}

Son yapılan yapısal eşitlik modellemesinde değerlerin uyum iyiliği indekslerine uygun çıkması sonucu (bkz. Tablo 3), değişkenler arasındaki ilişkinin incelenmesi için ilişki katsayılarına bakılmıştır. Tablo 4'te görüldüğü üzere yapısal eşitlik modellemesi sonucu değişkenler arasında hesaplanan ilişki katsayılarına göre Akdeniz Üniversitesi için, akustik ve aydınlatma öğrenebilme durumunu etkilerken; hava kalitesi, akustik ve öğrenebilme durumunun ziyaret süresini etkilediği tespit edilmiştir. Sayısal verilere göre bu değerler arasındaki en yoğun etkileşim öğrenebilme durumu ile ziyaret süresi arasındadır. Öğrenebilme durumu ise önce aydınlatma sonra akustik ile ilişkili çıkmıştır. Akustiğin kötü olması ve hava kalitesinin kötüleşmesi durumlarında da kullanıcı ziyaret süresinin kısaldığı tespit edilmiştir.

Ön model kurulurken önemli olacağı varsayılan ve bu nedenle anket sorularının çoğunluğunu oluşturan mimari özelliklerin -(mekân kurgusu ve Wi-fi, priz sıklığ1 vb. mekânsal olanaklar) son analizlerde önemli bir faktör olmaktan çıktığı gözlenmektedir. Mimari açıdan dikkat çekici bu sonucun ortaya çıkmasında teknolojinin ilerlemesiyle kaynak ihtiyacının çevrimiçi yollardan daha hızlı ve kolay sağlanması ve bireysel çalışmanın artmasıyla mekân içerisinde sunulan fiziksel olanakların kullanıcılar tarafından kişisel olarak da karşılanabilmesi önemli etkenlerdir. Artık kullanıcılar yanlarında taşıdıkları bireyselleşmiş Wi-fi ya da güç kaynağı olanakları ile mekânsal imkânlardan bağımsızlaşmışlardır.

Mekânsal kurgunun bir tercih sebebi olarak görülmemesi alternatif olmaması ile açıklanabilir. Mekânsal kurgu ve çalışma olanakları, genel olarak kullanıcıların kütüphaneyi kullanma tercihindeki artışta önemli etkenler olabilir. Ancak Akdeniz Üniversitesi kampüsünde tek bir kütüphane olması nedeniyle kullanıcıların başka bir alternatifi yoktur. Bu sebeple mekânsal kurgu ve çalışma olanakları faktörlerinin, Akdeniz Üniversitesi Merkez Kütüphanesine ziyaret süresinde ve kütüphane içerisindeki öğrenim durumunda büyük bir düşüşe sebebiyet vermediği gözlenmektedir. Bunun yanı sıra kullanıcıların iyi bir kütüphane tasarımı hakkında fikir sahibi olmamaları da, böyle bir beklentinin yaratılmaması nedeniyle bu faktörün ayırıcı bir fark yaratamamasında bir etken olabilir. Daha iyi bir kütüphane tasarımı talebinin oluşması için öğrencilerin mekânlar arasında karşılaştırma yapabilecek kadar nitelikli modern kütüphane tasarımlarına aşina olmadıkları düşünülmemektedir.

İç hava kalitesi, Akdeniz Üniversitesi Kütüphanesi için ziyaret süresini etkileyen faktörlerden biri olarak tespit edilmiştir. Havasız ortamlar, insan sağlığını olumsuz etkilemekle birlikte, kullanıcının çalışma performansını da düşürmektedir (Çilingiroğlu, 2010, s.25). Çalışma alanlarındaki 1sıl konforun ve iç hava kalitesinin çalışanlar üzerinde fiziksel ve psikolojik etkileri bulunmaktadır; çalışma ortamının iklimlendirmesinin yeterli olması, kullanıcıların verimli çalışmasında büyük etkiye sahiptir (Özdamar ve Umaroğulları, 2017, s.38). Antalya kentinde binalarda iklimlendirme sorunu yazın sıcak kışın ise nemli ve yağışlı 
iklimi dolayısıyla klimatize ortamların önemini daha da artırmaktadır. Akdeniz Üniversitesi kütüphanesinde doğal havalandırma kullanılmamaktadır. İç mekânda hava dolaşımı merkezi iklimlendirme sistemi ve salon tipi klimalarla sağlanmaktadır. Anket sürecinde kullanıcıların çoğunluğu, iç mekân hava kalitesinden memnun olmadıklarını ve çalışma süresince mola sürelerini buna bağlı olarak artırdıklarını belirtmişlerdir.

Akdeniz Üniversitesi Kütüphanesi için aydınlatma faktörü, öğrenebilme durumunu, dolayısıyla kütüphaneye ziyaret süresini etkileyen en önemli unsurdur. Yapılar mekânın işlevine uygun bir şekilde tasarlandığında ve aydınlatma ögeleri yapının mimarisi ile bütünleştiğinde, kullanıcının mekân algısı olumlu yönde etkilenmektedir. Aydınlatma tasarımında da yapay ve doğal aydınlatma birlikte düşünülüp uygulandığında hem enerji tasarrufu sağlanır hem de araştırmacıların çalışma performansında artış görülür (Ataç, 2013, s.47). Akdeniz Üniversitesi Kütüphanesinde yapının merkezinde doğal 1şıł alan bir galeri ile birlikte bina çeperinde sık ve uygun genişlikte pencereler bulunmaktadır. Bu tasarım doğal aydınlatma için kullanıcılara büyük avantaj sağlamaktadır. Galeri ve çeperdeki pencereler arasında kalan bölümlerde yapay aydınlatıcı olarak parabolik armatürler kullanılmaktadır. Doğal aydınlatma çalışma alanlarında yeterli bulunsa da kitap raflarında bu aydınlık seviyesinin yetersiz kaldığı kullanıcılar tarafından belirtilmiştir. Yapay aydınlatmanın ise akşam saatlerinde, özellikle üst katlarda yetersiz olduğu tespit edilmiştir (bkz. Şekil 8).
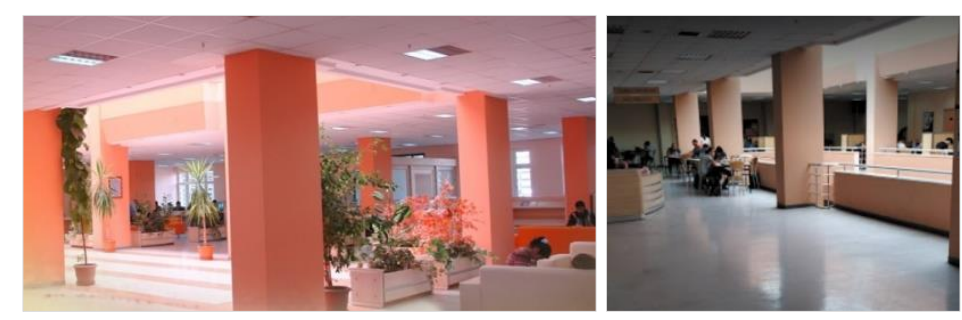

Şekil 8. Akdeniz Üniversitesi Merkezi Kütüphane iç mekân aydınlatması, Sol; (Akdeniz Üniversitesi, t.y.), Orta; (Google Fotoğraflar, t.y.)

Son olarak sessizlik kavramı kütüphaneye gitmede en önemli tercih sebeplerindendir. Akustik Akdeniz Üniversitesi Merkez Kütüphanesi için hem öğrenebilme durumunu hem de ziyaret süresini etkilediği için önemli bir faktördür. Her ne kadar anket sorularında bulunan klavye sesi ve yürüme seslerinin kullanıcıları rahatsız ettiği tespit edilse de Akdeniz Üniversitesi Kütüphanesinde kullanıcılar, gürültünün en büyük kaynağının mekân içerisindeki klima vb. ses çıkaran aletler olduğunu belirtmiştir. Bu tür seslerin kullanıcı konsantrasyonunun bozulmasına ve öğrenme verimliliğinin azalmasına neden olduğu gözlenmektedir. Sonuçlar iç mekân tasarımda ses yalıtımı için malzeme seçiminin önemi kadar mekân kurgusunun da önemini ortaya çıkarmaktadır. Mekân kurgusunda bilgisayar kullanıcılarının olduğu bölümlerin belirlenmesi ve bu bölümlerdeki mobilya ve kaplamaların seçimi ile aletlerinin sebep verdiği gürültünün engellenmesi sağlanabilir. Akustik faktörü, analizlerde görüldüğü üzere, birçok değişkeni doğru ve dolaylı yoldan etkilediği için kullanıcıların kütüphane ziyaretinde önemli bir etkiye sahiptir. 


\section{Sonuç}

Halk kütüphaneleri ve diğer kütüphane çeşitlerine kıyasla akademik ihtiyaçlara karşıllı veren üniversite kütüphanelerinin fonksiyonel işleyişi ve bu işleyiş farkının doğurduğu mimari daha özneldir. Kütüphanelerin kullanıcı ihtiyaç ve istekleri temel alınarak tasarlanması ya da iyileştirilmesi gerekir. Bunun için kullanıcı ihtiyaçları hakkında literatür taraması yapılmış ve değişkenler tespit edilmiştir. Oluşturulan değişken şemasına analizler uygulanmış ve faktörler elde edilmiştir. $\mathrm{Bu}$ analizlere göre Akdeniz Üniversitesi öğrencileri için kütüphane kullanımında akustik, aydınlatma ve hava kalitesi önemli etkenler olarak öne çıkmıştır.

Kullanıcılar kütüphaneyi kullanırken hızlı konsantre olabilmeyi ister ve araştırma sürecinde konforlu bir çalışma ortamını talep ederler. Bu sürecin ilk aşaması, çalışırken çalışma alanının kullanıcı tarafından rahat bir şekilde görülmesiyle başlar. Araştırma alanının aydınlık seviyesi doğru bir şekilde sağlanmadığı sürece kullanıcı odaklanamaz ve araştırma süreci olumsuz etkilenir. Akdeniz Üniversitesi Kütüphanesinde aydınlatma için galeri, pencere ve armatür gibi birçok düzenleme yapılsa da, kullanıcı açısından görsel konforun yer yer eksik kaldı̆̆ 1 tespit edilmiştir.

Aydınlatmanın ardından tespit edilen bir diğer etken ise araştırma ortamında iyi bir hava kalitesinde çalışabilmektir. Havalandırmanın sürekli makinelerden sağlandığı veya tek başına doğal havalandırmanın da yeterli olmadığı durumlarda kullanıcı çalışırken bir süre sonra bunalabilir ve çalışmasını sonlandırabilir. Hem anket sürecindeki yüz yüze görüşmelerde hem de analiz sonuçlarında Akdeniz Üniversitesi Kütüphanesindeki hava kalitesinin önemli bir problem olduğu kullanıcılar tarafından belirtilmiştir.

Kullanıcılar için son sırada ise kısmen daha tolere edilebilir olan gürültü etmeni gelmektedir. Kullanıcıların, çalışma alışkanlıklarına bağlı olarak gürültü konusundaki hassasiyetleri değişebilir. Kütüphanede kulaklıkla müzik dinleyerek çalışanların çoğunlukta olduğu gözlemlenmiştir. Bu grup için klavye vb. gürültüler konsantrasyonu bozucu bir etmen değildir; ancak üniversite kütüphanesinde her tip kullanıcının çalışabileceği bir ortam yaratılması gerektiği için sessizlik talep eden kullanıcılara da uygun bir ortam sunulması beklenmektedir. Oysaki Akdeniz Üniversitesi Kütüphanesinde çalışma mekânları ortaktır. Çalışma alanlarında grup, bireysel veya bilgisayar ile araştırma gibi özelliklere dayalı bir mekânsal ayrım yapılmamıştır. Bunun kullanıcılar için problem oluşturduğu analiz sonuçlarından gözlenebilmektedir.

Anlaşılmaktadır ki aydınlatma, havalandırma ve akustik gibi birincil ihtiyaçlarda problem çıkması; mekânsal organizasyon, kütüphane mobilyası ve kütüphanenin mimari niteliği gibi ihtiyaçları kullanıcılar açısından önemsiz hale getirmiştir. Kütüphane yapı fiziği açısından yetersiz kaldığında ve dolayısıyla kullanıcıların temel ihtiyaçlarını karşılayamadığında, kullanıcı için kütüphanenin tasarım nitelikleri ikinci plana düşmüştür. Demek oluyor ki, kullanıcılar tarafından kütüphane tamamen fonksiyonel bir yapı olarak algılanmış ve kullanıcı beklentileri temel ihtiyaçlara indirgenmiştir. Bu sonuçlar, çalışmanın başlangıcında mekânsal niteliklerden biri olarak tasarım ile ilgili niteliklerin kütüphane kullanıcısını etkileyen faktörlerden biri olduğu varsayımını geçersiz kılmıştır. Sonuçlara göre Akdeniz Üniversitesi Merkez Kütüphane kullanıcılarının tasarım ile ilgili değil yapısal/fonksiyonel niteliklerden etkilendikleri, tasarım ile ilgili niteliklerin kullanıcıyı etkileyen mekânsal nitelikler içerisinde bulunmadı̆̆ 
Tespit edilen sorunlara göre yapılması gereken iyileştirme önerileri ise mobilya düzeyinde veya bina ölçeğinde olarak iki grupta önerilebilir. Dünya üzerinde mimari niteliği yüksek olarak kabul edilen kütüphane örneklerine bakıldığında iç mekânda esneklik hâkimdir. Mekânsal olarak bölünmeler minimumda ve bu sebeple mobilya tasarımı ve organizasyonu ile mekânsal olanaklar en iyi şekilde sağlanabilmektedir. Akdeniz Üniversitesi Merkez Kütüphanesinde de bölücü olarak duvar ayracı neredeyse bulunmadığı için kütüphane esnek tasarıma ve alanın yeniden organizasyonuna açıktır. Taşınabilir ve yeniden düzenlenebilir, esnek ve kullanıcı odaklı tasarlanmış mobilyalar ve mekânlar ile kütüphanedeki birçok problem giderilebilir. Analiz sonuçlarına göre çıkan en büyük üç problemden biri olan aydınlatma problemi mobilya düzenlemesi ile çözülebilir. Kullanıcı odaklı yeni tasarlanacak raf ve masa ile ya da mevcut raf ve masalara yapılacak eklentiler ile kullanıcının görüş konforu sağlanabilmektedir. Akustik problemin çözümünde farklı faktörler etkili olmasından kaynaklı ayrı ayrı çözümler düşünülmelidir. Yaya yürüyüşünden çıkan gürültü, zeminin malzeme türünden kaynaklanmaktadır. Zeminde kauçuk levha gibi darbe emici malzeme kullanımı ile gürültü engellenebilir. Grup çalışması, klavye tıklamaları gibi kullanıcı kaynaklı gürültülerin çözümü mekânsal olarak yapılabilmektedir. Örneğin; grup çalışması için mekân içerisinde ayrılan bölümler veya bilgisayarla çalışanlar için farklı alanların organizasyonu ile çözüm sağlanabilmektedir. Akustik paravan kullanımı da farklı bir çözüm önerisi olabilmektedir. Otomat, klima gibi makine ve aletlerden çıkan gürültüler de farklı makine seçimi veya alan organizasyonu ile çözüme kavuşabilmektedir. İç mekân hava kalitesi problemi ise güçlü bir iklimlendirme sistemi ile çözülebilir. Bina çeperindeki pencerelerin yeniden tasarlanıp düzenlenmesi ile doğal havalandırmanın güçlendirilmesi de mümkündür. Merkez kütüphanenin iyileştirilmesinin yanı sıra bina ölçeğinde yapılacak yenilikler ile birtakım problemler çözülebilir. Örneğin; yapıya eklenti yapılarak kapasite artışına çözüm sağlanabilir veya kampüsün başka bir odak noktasına yeni bir kütüphane yapılarak ulaşım sorunu giderilebilir.

Akdeniz Üniversitesi Kütüphanesinde yapılan bu çalışmaya göre ilgili analizler sonucunda çıkan bu faktörlerin iyileştirilmesi veya korunması ile kütüphane ziyaretinde ve çalışma verimliliğinde önemli artışlar sağlanabileceği öngörülmektedir. Mimari ve iç mimari tasarım niteliklerinin kütüphane cazibesine ve kullanıcı memnuniyetine etkisi ile ilgili bir çalışmanın ise ancak bu aşamadan sonra yapılabileceği düşünülmektedir. Yükseköğretim Kurulunun (2014, s.4) yayımladığı raporda da belirtildiği üzere, Türkiye'deki üniversite kütüphanelerinin genellikle yetersiz olduğu söylenebilir. Oysaki bu mekânların tasarım ile ilgili niteliklerinin geliştirilmesi onları kullanıcılar için tercih edilen bir üçüncü mekâna dönüştürebilir ve yükseköğrenimin başarısının artmasına katkıda bulunabilir. Bu çalışma, mevcut kullanıcı ihtiyaçlarının tespiti doğrultusunda geliştirilmiştir; ancak yapılacak yeni üniversite kütüphaneleri için kullanıcıların sosyokültürel alışkanlıklarının zaman içerisinde değişebileceği de göz önünde bulundurulmalıdır. Kütüphaneler her zaman dinamik ve çağa uyum sağlayan yapılar olmalıdır; böylece ülkelerin gelişmesindeki en önemli etken olan akademik çalışmalara önemli derecede katkı sağlayabilirler. 


\section{Kaynakça}

Aabø, S. ve Audunson, R. (2012). Use of library space and the library as place. Library \& Information Science Research 34, 138-149.

Akdeniz Kampüs Haber. (2016, 17 Ocak). Kütüphanelere yoğun ilgi. Erişim adresi: http://akdenizkampushaber.blogspot.com/2016/01/kutuphane-yine-bildigimiz-gibi.html

Akdeniz Üniversitesi. (t.y.). Kütüphane ve dokümantasyon daire başkanlığı. Erişim adresi: http://kutuphane.akdeniz.edu.tr/

Altuğ, B. G. (2019). Üniversite kütüphanelerinin mekânsal analizi (Yayımlanmamış yüksek lisans tezi) Yıldız Teknik Üniversitesi, İstanbul.

Archello. (t.y.). Peckham Library. Erişim adresi: https://archello.com/project/peckham-library

Ataç, F. (2013). Kütüphanelerde doğal ve yapay aydınlatma kriterleri: Orta Doğu Teknik Üniversitesi Merkez Kütüphanesinin okuma salonlarının incelenmesi (Yüksek lisans tezi, Atılım Üniversitesi, Ankara). Erişim adresi: https://docplayer.biz.tr/4191990-Kutuphanelerde-dogal-ve-yapayaydinlatma-kriterleri-orta-dogu-teknik-universitesi-merkez-kutuphanesinin-okuma-salonlarininincelenmesi.html

Banbury, S., ve Berry, D. (1998). Disruption of office-related tasks by speech and office noise. British Journal of Psychology, 89, 499-517.

Büyüköztürk, Ş. (2002). Faktör analizi: Temel kavramlar ve ölçek geliştirmede kullanımı. Kuram ve Uygulamada Eğitim Yöntemi. 32, 470-483.

Castilla, Llinares, Bravo ve Blanca (2017). Subjective assessment of university classroom environment. Building and Environment, 122, 72-81.

Choi, S. M., Guerin, D. A., Kim, H.-Y., Brigham, J. K. ve Bauer, T. (2013-2014). Indoor environmental quality of classrooms and student outcomes: A path analysis approach. Journal of Learning Spaces, 2(2), 2013-2014. Erişim adresi: http://libjournal.uncg.edu/jls/article/view/506/513

Çilingiroğlu, S. (2010). İç hava kalitesi. Tesisat Mühendisliği, 115, 23-42. Erişim adresi: http://www1.mmo.org.tr/resimler/dosya_ekler/7f2a4ea3bedd425_ek.pdf.

Demir, G. (2019, 10 Mayıs). Üçüncü mekan: Kütüphanelerin değişen ve gülen yüzü. Erişim adresi: https://www.bbyhaber.com/bby/2019/05/10/ucuncu-mekan-kutuphanelerin-degisen-ve-gulenyuzu-guler-demir-kastamonu-universitesi-bby (Erişim tarihi: 01.06.2020)

Dursun, Y. ve Kocagöz, E. (2010). Yapisal eşitlik modellemesi ve regresyon: Karşılaştırmalı bir analiz. Erciyes Üniversitesi İktisadi ve İdari Bilimler Fakültesi Dergisi, 35, 1-17.

Everaert, P. Opdecam, E. ve Maussen, S. (2017). The relationship between motivation, learning approaches, academic performance and time spent. Accounting Education, 26(1), 78-107.

Fraley, R. A. ve Carol L. A. (1990) Library Space Planning: A How-To-Do-It Manual for Assessing, Allocating and Reorganizing Collections, Resources and Facilities. New York, London, NealSchuman Publishers.

Groth, A. (2007). Energy Efficiency Building Design Guidelines for Botswana. Bostwana: Department of Energy, Ministry of Mineral, Energy And Water Resources.

Google Fotoğraflar. (t.y.). Akdeniz Üniversitesi Merkez Kütüphane fotoğrafları. Erişim adresi: https://bit.ly/2Cm6BSn

Google Popüler Saatler. (t.y.). Akdeniz Üniversitesi Merkez Kütüphane. Erişim adresi: https://bit.ly/3hEIoGY 
Google Popüler Saatler. (t.y.). TU Delft Library. Erişim adresi: https://www.google.com/search?q=delft+library\&oq=delft+library\&aqs=chrome..69i57j016.386 $4 \mathrm{j} 0 \mathrm{j} 4 \&$ sourceid $=$ chrome\&ie $=\mathrm{UTF}-8$

Göktekin, E. (2002). Ortaöğretim yapılarında yeni ĕgitim teknolojilerinin yoğun olarak kullanıldiğ mekanların kullanım sürecinde değerlendirilmesi (POE/KSD) (Yüksek lisans tezi). Erişim adresi: https://polen.itu.edu.tr/handle/11527/8480

Head, A. J. (2016). Planning and designing academic library learning spaces: Expert perspectives of architects, librarians, and library consultants. (Araştırma raporu) Project Information Literacy web sayfasından erişildi. projectinfolit.org/uploads/2/7/5/4/27541717/pil_libspace_report_12_6_16.pdf

JISC. (2006). Designing spaces for effective learning: A guide to 21st century learning space design. Erişim adresi: https://issuu.com/gfbertini/docs/designing_spaces_for_effective_learning__a_guide_

Aydoğan, H. (2017). İstanbul'daki Üniversite Kütüphanelerinde Mekan Ile Kullanıcı Ilişkilerinin Sentaktik Olarak Irdelenmesi. (Yayımlanmamış yüksek lisans tezi) İstanbul Teknik Üniversitesi, İstanbul.

Hohmann, T. (2006). New aspects of library design. Liber Quarterly,16 (2), . doi: 10.18352/lq.7841.

IBM. (t.y.). IBM SPSS AMOS. Erişim adresi: https://www.ibm.com/tr-tr/marketplace/structuralequation-modeling-sem

Kılıç, S. (2016). Cronbach'ın alfa güvenirlik katsayısı. Journal of Mood Disorders, 6(1), 47-48. doi: 10.5455/jmood.20160307122823

Kul, S. (2014). İstatistik sonuçlarının yorumu: P değeri ve güven aralığı nedir? Türk Toraks Derneği, 11-13. doi:10.5152/pb.2014.003

Kuru, R. ve Türkyılmaz, Ç. C. (2019). Kütüphane yapılarının mekansal organizasyonunun ergonomik açıdan değerlendirilmesi: Bahçeşehir Üniversitesi Kütüphane binası örneği. Ergonomi. 2(3), 153166. doi: 10.33439/ergonomi.481138

Küçükcan, B. (2005). Üniversitelerde kütüphane binaları kullanım verimliliğinin yapı biyolojisi açısından incelenmesi (Doktora tezi). Erişim adresi: http://bbytezarsivi.hacettepe.edu.tr/jspui/bitstream/2062/454/1/195.pdf

Küçükcan, B., Balanl1, A., Öztürk, A. ve Vural, M. (2007). University library buildings in Turkey: A survey and a case study of Y1ldiz Technical University main library building. The Journal of Academic Librarianship, 33(6), 714-718. doi: 10.1016/j.acalib.2007.09.006

Lee, M. C., Mui, K. W., Wong, L. T., Chan, W. Y., Lee, E. W. M. ve Cheung, C. T. (2012). Student learning performance and indoor environmental quality (IEQ) in air-conditioned university teaching rooms. Building and Environment, 49, 238-244. doi: 10.1016/j.buildenv.2011.10.001

Leighton, P. D. ve Weber, D. C. (1999). Planning academic and research library buildings (3. bs.). Erişim adresi:

https://books.google.com.tr/books?hl=tr\&lr=\&id=Q8R9UH8kbo4C\&oi=fnd\&pg=PR17\&dq=ex pansion+of+academic+library+building+design\&ots=hJJY5i3xbl\&sig=Dm399dzmpTAJCaerdj $4 \mathrm{YXuFcM} 3 \mathrm{k} \&$ redir_esc $=\mathrm{y} \# \mathrm{v}=$ onepage $\& \mathrm{q} \& \mathrm{f}=$ false

Li, H. L., Wu, F. ve Su, B. (2018). Impacts of library space on learning satisfaction - An empirical study of university library design in Guangzhou, China. The Journal of Academic

Librarianship, 44(6), 724-73. doi: 10.1016/j.acalib.2018.10.003

Lynch, C. (2000, Ocak). From automation to transformation: Forthy years of libraries and information technology in higher education. Educause Review. Erişim adresi: 
https://er.educause.edu/articles/2000/1/from-automation-to-transformation-forty-years-oflibraries-and-information-technology-in-higher-education

Mecanoo. (t.y.). Library Delft University of Technology. Erişim adresi: https://www.mecanoo.nl/Projects/project/27/Library-Delft-University-of-Technology?t=0

Oldenburg, R. (1991). The great good place: Cafés, coffee shops, bookstores, bars, hair salons and other hangouts at the heart of a community. New York: Marlowe.

Özdamar, M. ve Umaroğulları, F. (2017). Bir ofis yapısı örneğinde 1sıl konfor ve iç hava kalitesinin incelenmesi. Megaron, 12(1), 27-40. doi: 10.5505/megaron.2017.02259

Peitx, I. B. (2017). Innovative architecture for the contemporary library. Universitat de Barcelona, 38 Erişim adresi: http://bid.ub.edu/pdf/38/en/bonet.pdf

Polat, C. ve Odabaş, H. (2011). Türkiye'de üniversite kütüphaneleri: Standartlar ve yönetici görüşleri doğrultusunda niceliksel bir değerlendirme. Atatürk Üniversitesi Sosyal Bilimler Enstitüsü Dergisi, 15 (1), 43-62.

Rasmussen, C. R. ve Jochumsen, H. (2009). The fall and rise of the physical library. 17. BOBCATSSS Sempozyumunda sunulan bildiri, Porto, Portekiz. . Erişim Adresi: http://eprints.rclis.org/12925/1/40.pdf

Kütüphane İstatistikleri, 2015 (2016, Ağustos). Türkiye İstatistik Kurumu Haber

Bülteni, 21545. Erişim adresi: http://www.tuik.gov.tr/PreHaberBultenleri.do?id=21545

Türk Dil Kurumu. (1988). Türkçe sözlük. Ankara: TDK.

Yaşlığlu, M. (2017). Sosyal bilimlerde faktör analizi ve geçerlilik: Keşfedici ve doğrulayıcı faktör analizlerinin kullanılması. İstanbul Üniversitesi İşletme Fakültesi Dergisi, 46, 74-85.

YÖK. (2014). 2023'e Doğru Türkiye'de üniversite kütüphaneleri mevcut durum, sorunlar, standartlar ve çözüm önerileri. Erişim adresi: https://docplayer.biz.tr/149852-2023-e-dogru-turkiye-deuniversite-kutuphaneleri-mevcut-durum-sorunlar-standartlar-ve-cozum-onerileri.html 


\section{Ek 1. Anket soruları}

Akdeniz Üniversitesi Merkezi Kütüphane Çalışma Ortamı Memnuniyeti Üzerine Bir Anket

1. Bölüm: Kişisel bilgilerinizden ve ögrenme davranışlarınızdan oluşmaktadır.

1. Katılımcının Cinsiyeti a. Erkek b.Kadın

2. Yaşınız

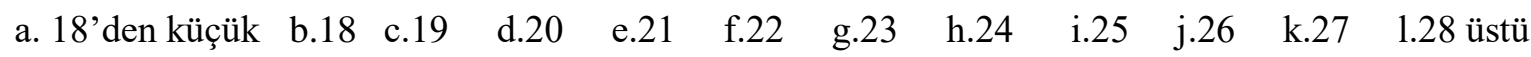

3. Akdeniz Üniversitesindeki Öğrenim Durumunuz

a. Lisans 1. Sinıf b. Lisans 2. Sinıf c. Lisans 3. Sinıf d. Lisans 4. Sinıf e. Yüksek lisans 1. Sinıf

f. Yüksek lisans 2. Sınıf g. Doktora öğrencisi h. Öğretim Görevlisi / Araştırmacı i. Diğer

4. Hangi Fakültede/Yüksekokuldasınız?

5. Merkezi Kütüphaneyi ne sıklıkla ziyaret etmektesiniz?

a. Hiç b. Haftada bir kez c. Haftada $2 \mathrm{kez}$ d. Haftada $3 \mathrm{kez}$ e. Haftada $4 \mathrm{kez}$ f. Haftada $5 \mathrm{kez}$ g. Haftada $6 \mathrm{kez}$ h. Haftada $7 \mathrm{kez}$ i. Ayda 1-3 kez j. Diğer

6. Kütüphanede günde ortalama ne kadar süre harcamaktasınız?

a. 0-2 saat a. 2-4 saat a. 4-6 saat a. 6-8 saat a. 8-10 saat a. 10-12 saat a. 12-14 saat a. +14 saat

7. Kütüphanede içerisindeki öğrenme verimliliğiniz hakkında ne düşünüyorsunuz?

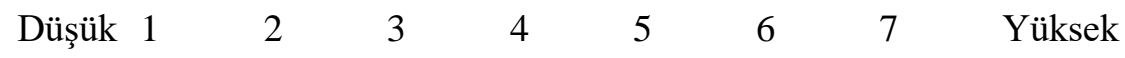

8. Kütüphanede içerisinde çalışırken ne kadar kolay konsantre olabiliyorsunuz?

$\begin{array}{llllllllll}\text { Kolay konsantrasyon } & 1 & 2 & 3 & 4 & 5 & 6 & 7 & \text { Hızlı dikkat dağılımı }\end{array}$

2. Bölüm: Kütüphanedeki öğrenme ortamı memnuniyetiniz üzerine odaklanmaktadır.

9. Klavye tıklama sesleri

10. Yürüme sesi (Ayak sesi vb.)

11. Makine - Alet sesleri (Klima vb.)

12. Çalışma alanlarının doğal aydınlık seviyesi

13. Çalışma alanlarının yapay aydınlatma seviyesi

14. Elektronik ekran görünürlüğü (Yansıma vb.)

15. İç mekan sıcaklığı

16. İç mekan nemi

17. İç mekan havalandırması

18. Çalışma masası konforu

19. Sandalye konforu

20. Kitap raflarının düzeni

21. Priz sıklı̆ 1

22. Wifi gücü

23. Depolama alanı (Eşyaların konulabileceği alanlar)

24. Kütüphane koleksiyonu yeterliliği

(Kitapların sayısı, çeşidi vs.)

25. Çalışma alan kurgusu

26. Kişisel çalışma alanı yeterliliği

27. Ortak çalışma alanı (Grıp çalışması vb.)

28. Sesli, sessiz çalışma alanlarının yeterliliği

29. Kişisel araç kullanım kolaylığ 1 (yaya, kişisel bisiklet, araba vs.)

30.Toplu taşıma kullanım kolaylığı

31. Genel kütüphane çalışma ortamı
Memnun değil 12334567 Memnun Memnun değil 122345567 Memnun Memnun değil 122345567 Memnun Memnun değil 122345567 Memnun Memnun değil 12234567 Memnun Memnun değil 12234567 Memnun Memnun değil 122345567 Memnun Memnun değil 12234567 Memnun Memnun değil 122345667 Memnun Memnun değil 112344567 Memnun Memnun değil 12234567 Memnun Memnun değil 122345567 Memnun Memnun değil 122345567 Memnun Memnun değil 12234567 Memnun Memnun değil 122345667 Memnun Memnun değil 12234567 Memnun

Memnun değil 12234567 Memnun Memnun değil 12234567 Memnun Memnun değil 12234567 Memnun Memnun değil 12234567 Memnun Memnun değil 122345567 Memnun Memnun değil 122345567 Memnun Memnun değil 12234567 Memnun 


\section{Summary}

Although the user needs and requests have been diversified in architecture as well as in many disciplines by the change of time, the buildings must be satisfactory for users for a long period. Therefore, architects should try to design a building not only concordant with its age but flexible enough to fit future needs. A functionally rigid structure can make it unusable in the long term. University libraries are one of the buildings that are always dynamic, and these buildings have to keep up with the time. University libraries are one of the most important public buildings that help countries to develop scientifically. Libraries should provide the best working spaces and research environment for students and academicians, as well as should be able to adapt to the change of the digital age.

At Akdeniz University, with a capacity of 74,000 students, the sample size of the questionnaire was calculated as 380, with a 5\% margin of error. A survey study, which is conducted by South China University of Technology (SCUT), was adapted for Akdeniz University Central Library. The survey collected data about student's demographic data, physical facilities of the library, the duration of student visits to the library, and the learning efficiency in the library. In this study, the relationship between the physical possibilities of the library, the duration of the student's visits to the library, and learning efficiency was questioned. The survey was applied to 392 participants, and 383 results were found appropriate. The questionnaire data were primarily analyzed in the SPSS program for reliability analysis, and the answers were found to be consistent in the survey. Later, with Factor analysis, essential factors were determined for users. Finally, the factors obtained and verified were combined in a single model in the Amos program, and causalities are examined.

Acoustic, lighting, air quality, study facilities, working area, and accessibility are predicted as the six main factors, which consist of 22 independent variables. It was observed that it decreased to 3 main factors: air quality, acoustics, and lighting. Although accessibility, spatial design, and library facilities also take certain values, in the central library of Akdeniz University, the factors that have significant effects on user satisfaction, the frequency and duration of library visits are acoustics, lighting, the quality of air and the educational status of users.

Looking at the causality model made in Amos, as well as effects of acoustics and lighting on the learning status, air quality, acoustics, and learning status, are determined to affect the duration of the visits, too. According to the numerical data, the most intense interaction is between the state of learning and the length of the visit. Learning status was associated first with lighting, and then acoustics. It was also determined that the duration of the user's visits is shorter in case of bad acoustics and poor air quality.

Consequently, it is understood that problems arise in primary needs, such as lighting, ventilation, and acoustics. In the absence of these, the architectural organization of the space, and the interior design of the library furniture have become insignificant needs of the user. Through this study, it is predicted that as improving these primary factors, significant increases in working efficiency and library visits can be achieved. It will be seen that a study on the effect of architectural features on the use of a library can only be made after this process. 